\title{
Bignoniaceae Juss. no Parque Nacional Vale do Catimbau, Pernambuco
}

\author{
Bignoniaceae Juss. in the Catimbau Valley, Pernambuco
}

\author{
Lucilene Lima dos Santos ${ }^{1,4}$, Leidiana Lima dos Santos ${ }^{2}$, Andrêsa Suana Argemiro Alves ${ }^{3}$, \\ Luciana dos Santos Dias de Oliveira ${ }^{2} \&$ Margareth Ferreira de Sales ${ }^{2}$
}

\begin{abstract}
Resumo
O Parque Nacional Vale do Catimbau está localizado entre o agreste e o sertão pernambucano e apresenta grande diversidade florística. O tratamento taxonômico das espécies de Bignoniaceae foi realizado através da análise morfológica de materiais coletados e herborizados. Dez espécies foram reconhecidas e distribuídas em oito gêneros: Anemopaegma Mart. ex Meisn., Cuspidaria DC., Fridericia Mart., Handroanthus Mattos, Jacaranda Juss., Mansoa DC., Pyrostegia C. Presl e Tabebuia Gomes ex DC. As espécies distribuem-se, principalmente, em áreas de Caatinga, sendo $P$. venusta encontrada também em floresta úmida. Chave de identificação, ilustrações e comentários sobre as espécies são apresentados.

Palavras-chave: Caatinga, florística, ipê, lamiales, taxonomia.
\end{abstract}

\begin{abstract}
The Valley of the Catimbau is a microregion located in rural Pernambuco which is highly diverse. The taxonomic survey of the Bignoniaceae species was accomplished by morphological analysis of material collected in the field, as well as herbarium material. Ten species are recognized and distributed in eight genera: Anemopaegma Mart. ex Meisn., Cuspidaria DC., Fridericia Mart., Handroanthus Mattos, Jacaranda Juss., Mansoa DC, Pyrostegia C. Presl e Tabebuia Gomes ex DC. The species are distributed mainly in the Caatinga, $P$. venusta is also found in the rainforest. A key for the identification of species, illustrations and comments about the species conservation status, are provided.
\end{abstract}

Key words: Caatinga, floristic, ipê, lamiales, taxonomy.

\section{Introdução}

Bignoniaceae Juss. compreende 82 gêneros e cerca de 827 espécies com distribuição pantropical (Lohmann \& Ulloa 2011). O Brasil é um dos centros de dispersão e de diversidade da família (Gentry 1973) com 32 gêneros e 391 espécies (Lohmann 2013).

A família é caracterizada por apresentar plantas predominantemente lenhosas, com folhas, em geral, compostas e opostas, flores bissexuadas, gamopétalas com tubo e lobos bem definidos, bilabiadas, frequentemente com 4 estames férteis, didínamos, e 1 reduzido a estaminódio, ovário súpero, quase sempre bilocular, raramente unilocular, com estilete terminal e estigma bilamelado, fruto cápsula septígrafa ou loculicida, raramente baga, e sementes aladas (Manning 2000; Judd et al. 2002; Souza \& Lorenzi 2008). Importantes estudos taxonômicos foram realizados por Bureau \& Schumann (1896-1897) e Gentry (1980; 1992; 1995), além de floras elaboradas por Lohmann \& Pirani (1996; 1998; 2003), Santos et al. (2009), entre outros.

Sistematicamente, a família está incluída entre as "Lamiids", ordem Lamiales (APG III 2009) e tem como grupo irmão o gênero Jacaranda Juss. (Olmstead et al. 2009). Estudos filogenéticos suportam o monofiletismo de Bignoniaceae com a exclusão da tribo Schlegelieae e do gênero Paulownia (Splanger \& Olmstead 1999). Trabalhos abordando os limites tribais e intergenéricos têm demonstrado as rotas evolutivas dentro da família (Zjhra et al. 2004; Chen et al. 2005; Lohmann 2006; Grose \& Olmstead 2007a, b; Li 2008). Contudo, devido à amostragem limitada de alguns táxons e a necessidade de análises de mais sequências nucleares e plastidiais os dados

\footnotetext{
${ }^{1}$ Instituto Federal de Pernambuco, Campus de Belo Jardim, Av. São Sebastião Rodrigues da Costa s/n, São Pedro, 55154-065, Belo Jardim, PE, Brasil.

${ }^{2}$ Universidade Federal Rural de Pernambuco, Depto. Biologia, Programa de Pós-Graduação em Botânica, R. D. Manoel de Medeiros s/n, Dois Irmãos, 52171-900, Recife, PE, Brasil. ${ }^{3}$ Universidade Federal Rural de Pernambuco, Depto. Biologia, Programa de Pós-Graduação em Etnobiologia e Conservação da Natureza, R. D. Manoel de Medeiros s/n, Dois Irmãos, 52171-900, Recife, PE, Brasil.

${ }^{4}$ Autor para correspondência: lucilenelima@gmail.com
} 
ainda são poucos conclusivos. Olmstead et al. (2009) analisando as sequências de cloroplasto $r b c \mathrm{~L}$, $n d h \mathrm{~F}$ e $t r n \mathrm{~L}-\mathrm{F}$ identificaram as linhagens primárias de Bignoniaceae, evidenciaram a família como monofilética e ainda reconheceram oito clados como tribos (Bignonieae, Catalpeae, Coleeae, Crescentieae, Jacarandeae, Oroxyleae, Tecomeae, Tourrettieae).

O Parque Nacional Vale do Catimbau está localizado na zona das Caatingas, subzona do Agreste e apresenta diversas fitofisionomias (Rodal et al. 1998; Gomes et al. 2006). Atualmente, é considerado área prioritária para conservação devido a grande diversidade biológica e por apresentar espécies raras (ex. Dyckia limae L.B. Sm, Jacaranda rugosa A. H. Gentry [Lohmann \& Silva-Castro 2009]) e endêmicas (ex. Acritopappus buiquensis Bautista \& D.J.N. Hind [Nakajima 2013], Jacaranda rugosa A. H. Gentry, Tillandsia catimbauensis Leme, W. Till \& J.A. Siqueira, Calliandra aeschynomenoides Benth. [Queiroz 2009]). Mesmo assim, poucos são os trabalhos florístico-taxonômicos desenvolvidos no Parque (Figueirêdo et al. 2000; Gomes et al. 2006; Rodal et al. 1998; Sales et al. 1998).

Dada à expressiva representatividade da família Bignoniaceae no Vale do Catimbau bem como a escassez de informações sobre a flora da área de estudo, o presente trabalho teve como objetivo reconhecer os gêneros e espécies de Bignoniaceae, ampliando assim, o conhecimento sobre o grupo e a flora de Pernambuco.

\section{Material e Métodos}

Área de estudo

O Parque Nacional Vale do Catimbau (PNVC), criado a partir da Lei Federal 913/12 (DOU 2002), está situado a $285 \mathrm{~km}$ do Recife, entre as coordenadas $8^{\circ} 24^{\prime} 00^{\prime \prime} / 8^{\circ} 36^{\prime} 35^{\prime \prime} \mathrm{S}$ e 37\%09'30"/ $37^{\circ} 14^{\prime} 00^{\prime \prime} \mathrm{W}$, abrangendo uma área de 62.300 ha na região do semiárido pernambucano. Toda sua extensão está inserida na microrregião do Sertão de Moxotó nos municípios de Buíque, Ibimirim, Inajá e Tupanatinga (MMA 2002). O PNVC está inserido no domínio da Caatinga e sua vegetação é composta por floresta úmida, vegetação rupestre e arbustiva perenifólia (Rodal et al. 1998) em solo arenoquartizolo profundo com inúmeras serras areníticas (Ferreira 2009).

\section{Coleta de material botânico}

e estudo taxonômico

O levantamento, identificação e descrição das espécies de Bignoniaceae do PNVC foram baseados em materiais coletados em campo (janeiro de 2011 a maio de 2012) onde os espécimes foram depositados no Herbário PEUFR; e em análise de materiais provenientes dos herbários HST (não indexado), IPA e UFP. Protólogos, bibliografias especializadas (Bureau \& Schumann 1896; 1897; Gentry 1982; MacBride 1961; Standley et al. 1974) e imagens de exemplares tipos também foram consultados. A designação das terminologias das estruturas vegetativas e reprodutivas foram fundamentadas em Radford et al.(1974) e Harris \& Harris (2001) e para venação Hickey (1973). As obras de Brummitt \& Powell (1992) e Stafleu \& Cowan (1989) foram adotadas para abreviações dos nomes dos autores e grafia das espécies, respectivamente.

\section{Resultados e Discussão}

Foram identificadas dez espécies, distribuídas em oito gêneros, destacando-se Fridericia Mart. e Handroanthus Mattos, ambos com duas espécies. As espécies ocorrem em áreas de Caatinga, exceto, Pyrostegia venusta (Ker. Gawl.) Miers. que também foi encontrada em regiões de florestas úmidas.

\section{Tratamento taxonômico}

Bignoniaceae Juss.

Árvores, arbustos ou trepadeiras, raramente ervas; pseudoestípulas comumente presentes, foliáceas ou inconspícuas; presença ou não de áreas glandulares na região interpeciolar; folhas pecioladas, opostas; lâminas compostas, raro simples, com o folíolo terminal geralmente substituído por uma gavinha. Inflorescências terminais ou axilares, racemosas, tirsos ou panículas, às vezes fasciculadas, ou reduzidas a uma única flor; flores bissexuadas, zigomorfas, diclamídeas; cálice tubular, campanulado ou urceolado, com bordo truncado, denteado, lobado, bilabiado ou espatáceo; corola 5-lobada, tubular, campanulada ou infundibuliforme; estames 4, raro 2 ou 5, inclusos ou exsertos, didínamos; estaminódio presente geralmente menor que os estames, frequentemente com tricoma glandular; anteras biloculares, rimosas, divaricadas ou paralelas, unidas por conectivo curto; ovário súpero, bilocular, raramente unilocular, com óvulos anátropos, dispostos em séries longitudinais; estilete terminal, estigma bilamelado. Fruto cápsula septígrafa ou loculicida, com ou sem formação de replo, ou fruto indeiscente, bacáceo; sementes geralmente aladas, alas orbiculares, hialinas ou amarronzadas. 


\section{Chave para a identificação das espécies de Bignoniaceae no PNVC}

1. Lianas; folhas bi ou trifolioladas.

2. Pseudoestípulas foliáceas; corola amarela; ovário glabro 1. Anemopaegma laeve

2'. Pseudoestípulas não foliáceas; corola não amarela; ovário lepidoto.

3. Ramos angulosos; gavinha trífida; estames exsertos 9. Pyrostegia venusta

3'. Ramos cilíndricos; gavinha simples ou ausentes; estames insertos.

4. Folíolos glabros; corola infundibuliforme 8. Mansoa difficilis

4'. Folíolos indumentados; corola tubular-campanulada ou estreitamente tubular-infundibuliforme.

5. Venação eucamptódroma; anteras retrorsas no botão floral; cápsula oblongo-linear com 4 alas cartáceas

2. Cuspidaria argentea

5'. Venação broquidódroma; anteras divaricadas no botão floral; cápsula linear achatada dorsiventralmente.

6. Folíolos membranáceos; cálice truncado; corola lilás

3. Fridericia dichotoma

6'. Folíolos fortemente cartáceos; cálice diminutamente 5-denticulado; corola branca

4. Fridericia limae

1'. Árvores e arbustos; folhas pinadas ou digitadas.

7. Folhas pinadas; estaminódio maior que os estames férteis, com tricoma glandular

7. Jacaranda rugosa

7'. Folhas digitadas; estaminódio menor que os estames férteis, sem indumento.

8. Folíolos cartáceos, oblongos a oblongos-ovados; cálice lepidoto

10. Tabebuia aurea

8'. Folíolos membranáceos a cartáceos, elípticos a ovais; cálice glabro a estrelado.

9. Ramos glabrescentes a estrelados; cálice com indumento estrelado-tomentoso; corola amarela 5. Handroanthus chrysotrichus

9'. Ramos glabros; cálice glabro; corola rósea a lilás 6. Handroanthus impetiginosus

Anemopaegma Mart. ex Meisn., Pl. Vasc. Gen. 1: 300. 1840 .

Lianas ou arbustos eretos; ramos subcilíndricos ou angulosos; pseudoestípulas foliáceas ou ausentes; folhas 2(-5)-folioladas, frequentemente com gavinha terminal, simples ou trífida, Inflorescência axilar ou terminal, racemo ou tirso; cálice cupular a campanulado, truncado; corola campanulada ou infundibuliforme, creme, branca ou amarela; estames inclusos; estaminódio reduzido; ovário elipsóide ou ovóideelipsóide; óvulos 2-6-seriados por lóculo. Cápsula septífraga, elipsóide a orbicular, estipitada; valvas paralelas ao septo, fortemente complanadas, lisas; sementes achatadas, orbiculares, alas hialinas, membranáceas, raro não aladas.

Gênero com 45 espécies ocorrendo nas América Central (Belize), do Norte (El Salvador, Guatemala, Honduras, México, Nicarágua, Panamá, Trinidad e Tobago) e do Sul (Argentina, Bolívia, Brasil, Equador, Guiana Francesa, Paraguai, Peru, Venezuela) (Lohmann \& Ulloa 2011).
1. Anemopaegma laeve DC., Prodr. 9: 189. 1845.

Fig. 1a-e

Liana; ramos cilíndricos, estriados, glabros; pseudoestípulas foliáceas, orbiculares; folhas 2-folioladas, gavinha simples, substituindo um dos folíolos; pecíolo 1,7-4 cm compr., cilíndrico, glabro; peciólulo 2-4 mm compr., folíolos 2,1-6,5 $\times 1-3,4 \mathrm{~cm}$, glabros, cartáceos, ovais, base obtusa a cordada, ápice agudo e mucronado, margem revoluta, broquidódroma, nervura mediana saliente, as demais inconspícuas. Inflorescência axilar, racemo, pauciflora, glabra; botões 1,1-4 × 0,5-1,2 cm, ápice arredondado; cálice $0,7-1,1 \times$ 0,6-1 cm, campanulado, truncado, glabro; corola infundibuliforme-campanulada, glabrescente, amarela, tubo $3,7-4,1 \times 1-1,5 \mathrm{~cm}$ na região mediana, lobos $0,8-1 \mathrm{~cm} \times 0,8-1 \mathrm{~cm}$, arredondados, brancos; estames com anteras 3,8-4,2 × 1,5 mm, divaricadas; filetes longos, $2,2-2,3 \mathrm{~cm}$ compr., filetes curtos 1,5-1,6 cm compr., estaminódio 6-8 mm compr., inseridos a $0,7-1,1 \mathrm{~cm}$ na base do tubo da corola; pistilo 1,8-2 cm compr.; ovário 2,5-3,1 × 


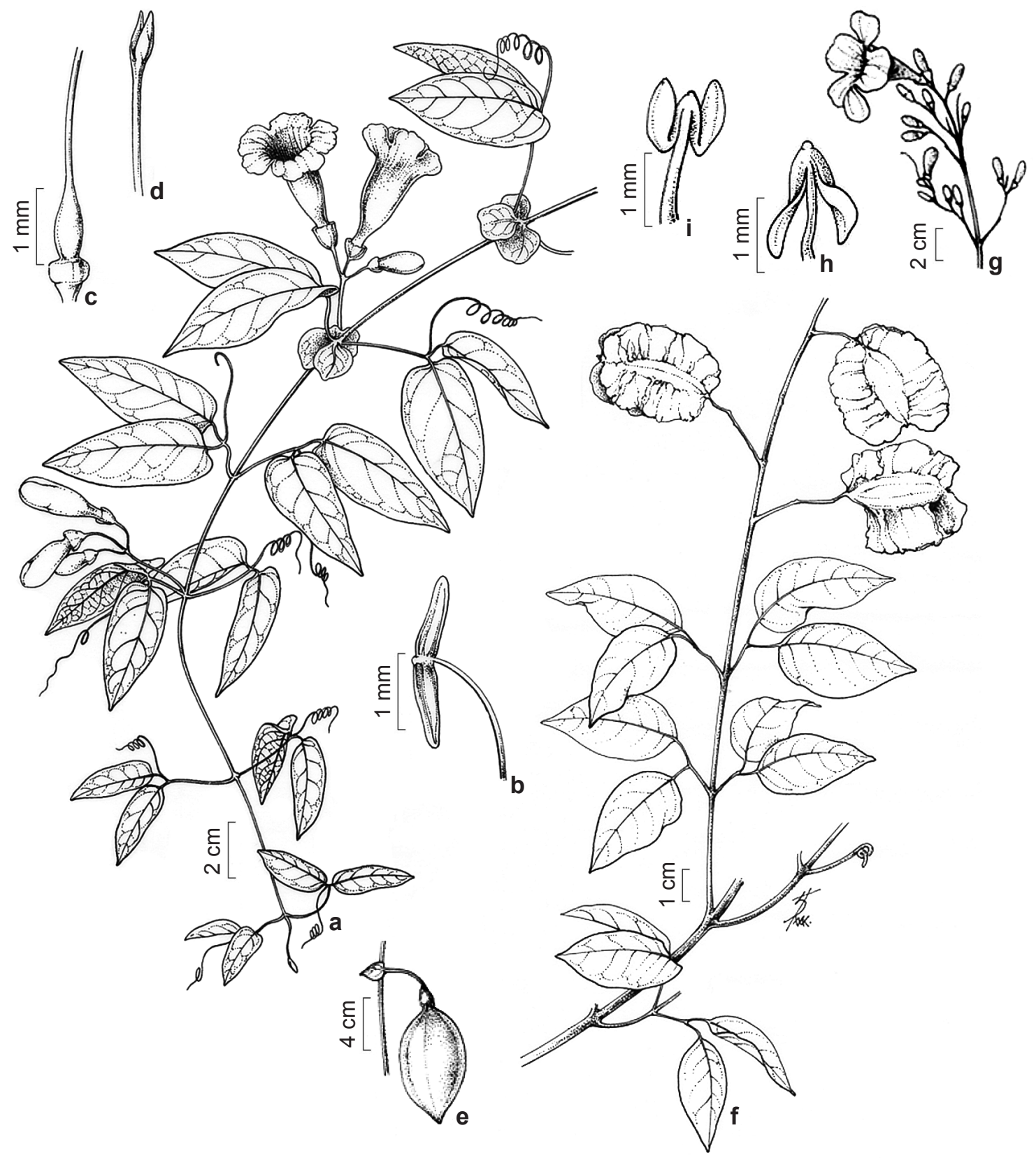

Figura 1 - a-e. Anemopaegma laeve DC - a. ramo florido; b. detalhe das anteras divaricadas; c. detalhe do disco nectarífero e ovário; d. detalhe do estigma bífido; e. cápsula orbicular. (a-e E. Freire et al. 34). f-h. Cuspidaria argentea (Wawra) Sandwith - f. ramo com frutos; g. inflorescência; h. anteras retrorses maduras; i. anteras retrorses imaturas. (f-h L.S. Figueirêdo et al. 110).

Figure 1 - a-e. Anemopaegma laeve DC - a. flowery branch; b. detail of anthers divaricate; c. detail of the nectariferous disk and ovary; d. detail of stigma bifid; e. capsule orbicular. (a-e E. Freire et al. 34). f-h. Cuspidaria argentea (Wawra) Sandwith - f. branch with fruits; g. inflorescence; h. mature anthers retrorses; i. immature anthers retrorses. (f-h L.S. Figueirêdo et al. 110). 
1,7-1,8 mm, elipsóide a ovóide-elipsóide, glabro, óvulos 2-seriados; disco nectarífero $2 \times 5 \mathrm{~mm}$, transversalmente elíptico. Cápsula 7-7,5 × 4,2$4,5 \mathrm{~cm}$, elipsóide a suborbicular, estipitada, lisa, glabra, lustrosa, base obtusa, ápice acuminado; sementes $0,7 \times 0,5 \mathrm{~cm}$, suborbiculares, alas hialinas, membranáceas.

Material examinado: Catimbau, 5.XII.1995, fl., $L$. Figueirêdo 266 (PEUFR); Estrada Buíque-Catimbau, 10.X.1995, fl., K. Andrade et al 235 (PEUFR); 10.I.1996, fr., M.J. Hora et al. 41 (PEUFR); 11.II.1995, fl., M.F. Sales 518 (PEUFR); 8.X.1971, fl., Andrade-Lima 25888 (IPA); Catimbau-Serrinha, 13.I.2011, fl., A.C.G. Costa 33 (IPA); Fazenda Laranjeiras, 20.V.1995, fl., E. Inácio et al. 55 (PEUFR); Serra do Catimbau, 18.X.1995, fl., A.M. Miranda 2272 (HST); fl., A.M. Miranda 2280 (HST); Sopé da serra, 12.I.1996, fl., E. Freire et al. 34 (PEUFR); Trilha das Torres, 17.III.1995, fl., A. Laurênio et al. 27 (PEUFR); 23.II.1996, fr., K. Andrade et al. 320 (PEUFR); Vale do Catimbau, Estrada para Igrejinha, 21.XI.2005, fl., A. Bocage 1051 (IPA); Estrada para a casa do artesão, 18.I.2012, fl., T.M.S. Melo 194 (PEUFR); Serra Branca, 2.V.2012, fl., L. Lima 95 (PEUFR), L.S. Oliveira 188 (PEUFR); Estrada para a casa do artesão, 18.I.2012, fr., T.M.S. Melo 184 (PEUFR); L.D.S. Oliveira 202 (PEUFR).

Endêmica do Brasil, frequentemente encontrada em áreas de Caatinga, incluindo formações de carrasco. No nordeste ocorre na Bahia, Ceará, Maranhão, Paraíba, Pernambuco e Piauí e no sudeste sua distribuição está restrita ao norte de Minas Gerais (Lohmann \& Pirani 2003; Lohmann 2013). No PNVC, a espécie foi coletada em vegetação perenifólia na encosta e no sopé da Serra do Catimbau. Anemopaegma laeve caracteriza-se pelas pseudoestípulas foliáceas, folhas 2-folioladas, folíolos cartáceos com a margem revoluta, corola amarela com lobos brancos e cápsula elipsóide a suborbicular. Floresce de outubro a março e frutifica de março a setembro. É popularmente conhecida como saboneteira.

Cuspidaria DC., Biblioth. Universelle Genève, II, 17: 125.1838.

Lianas; ramos com ou semáreas interpeciolares glandulares; pseudoestípulas pequenas, às vezes ausentes; folhas 2(-5)-folioladas, raro simples, geralmente com gavinha simples. Inflorescência terminal, panícula; cálice tubular, 5-denticulado, lacínios longos, conspícuos; corola tubularinfundibuliforme, azul-claro; anteras pubescentes ou glabras, divaricadas, curvadas na região mediana e fortemente reflexas; ovário linear-cilíndrico, lepidoto; óvulos 2-4-seriados por lóculo. Cápsula linear a oblonga; valvas lenhosas ou coriáceas, paralelas ao septo, com margens laterais aladas; sementes com alas hialinas, membranáceas.

Gênero com 16 espécies distribuídas do México a Argentina, com centro de diversidade no Brasil (Gentry 1973; Lohmann \& Ulloa 2011).

2. Cuspidaria argentea (Wawra) Sandw., Kew Bull. 9: 606. $1955 \quad$ Fig. 1f-h

Liana; ramos cilíndricos, com estrias transversais; pseudoestípulas inconspícuas; folhas 2-folioladas, gavinha simples, em geral caducas; pecíolo 1-1,3 cm compr., cilíndrico, tomentoso; peciólulo $0,5-1 \mathrm{~cm}$ compr., folíolos 3,4-5 × 1,5-2,8 $\mathrm{cm}$, face abaxial velutina a tomentosa, adaxial vilosa a tomentosa, membranáceos, ovais, base cuneada a arredondada, ápice agudo, margem inteira, eucamptódroma. Inflorescência terminal, tirso, multiflora; cálice ca. $3 \mathrm{~mm}$ compr., campanulado, truncado, glabro; corola tubular-infundibuliforme, glabrescente, rósea, tubo $4 \mathrm{~cm}$ compr.; corola tubular-infundibuliforme, azul-claro; anteras retrorsas no botão floral. Cápsula 3-4 × 0,9-1,2 $\mathrm{cm}$, oblongo-linear, glabra, com 4 alas cartáceas; sementes $0,7-1,1 \times 1-1,3 \mathrm{~cm}$, orbiculares, alas hialinas, membranáceas nas extremidades.

Material examinado: Fazenda Laranjeiras, 9.VII.1995, fr., L.S. Figuêiredo et al. 110 (PEUFR).

Material adicional: BRASIL. BAHIA: 1.I.1975, fl., R.M. Harley 16480 (IPA). PIAUÍ: Serra da Capivara, 1979, L. Emperaire 515 (IPA).

Espécie encontrada apenas no Nordeste, nos estados da Bahia, Ceará, Maranhão, Piauí e Pernambuco (Lohmann 2013). No PNVC ocorre em áreas de Caatinga arbustiva densa, em solos arenosos profundos na chapada de São José. Caracteriza-se por apresentar ramos com estrias transversais, folíolos com venação eucamptódroma e cápsula oblongo-linear, glabra, com 4 alas cartáceas. As informações da corola foram retiradas de Bureau \& Schumann $(1896 ; 1897)$. Frutifica em julho.

Fridericia Mart., Nova Acta Phys.-Med. Acad. Caes. Leop.-Carol. Nat. Cur. 13(2): 7. 1827.

Lianas, raramente arbustos ou pequenas árvores; ramos com áreas interpeciolares glandulares; pseudoestípulas pequenas, raramente inconspícuas; folhas usualmente 2-3-folioladas, com o folíolo terminal modificado em gavinha simples, raro folhas simples. Inflorescência terminal ou axilar, tirso, multiflora; cálice cupular, truncado, diminutamente 5-denticulado; corola tubular, campanulada ou infundibuliforme, púrpura, 
raro alvas, densamente pubescente na face externa, rósea; estames inclusos; anteras divaricadas, estaminódio reduzido; ovário oblongo, usualmente lepidoto, óvulos 2-4 seriados por lóculo; disco nectarífero presente. Cápsula septífraga, linear, achatada, valvas paralelas ao septo, aplanadas, lisas; sementes bialadas, alas hialinas.

Apresenta 69 espécies distribuídas do México até a América Tropical (Lohmann \& Ulloa 2011), das quais 56 são encontradas no Brasil (Lohmann 2013).

3. Fridericia dichotoma (Jacq.) L.G. Lohmann, Ann. Missouri Bot. Gard. 2010 in press.

Fig. 2a-c

Liana; ramos cilíndricos, estriados, glabros, lenticelas salientes, abundantes; pseudoestípulas inconspícuas; folhas 3-folioladas, gavinha ausente; pecíolo 2,8-3,4 cm compr., cilíndrico, tomentoso; peciólulo $0,3-1 \mathrm{~cm}$ compr., folíolos $2,1-6,5 \times$ $1-3,4 \mathrm{~cm}$, face abaxial tomentosa, face adaxial velutina, membranáceos, oblongo-elípticos, base arredondada a subcordada, ápice retuso a obtuso, margem plana, broquidódroma. Inflorescência terminal, tirso, multiflora, botões $0,5-1,5 \times 3-5$ $\mathrm{mm}$, ápice acuminado; cálice tubular, truncado, glabro; corola tubular-campanulada, externamente tomentosa, internamente glabra exceto na altura da inserção dos estames, lilás, tubo 2,8-3,7 × 1,1-1,3 $\mathrm{cm}$ na região mediana, lobos $0,8-1,7 \times 0,8-1,5$ $\mathrm{cm}$, arredondados; estames com anteras 3-3,5 $\times 1$ $\mathrm{mm}$, divaricadas; filetes longos 1,8-1,9 cm compr., filetes curtos 1,3-1,4 cm compr., estaminódio 4-5 $\mathrm{mm}$ compr., inseridos 3-6 $\mathrm{mm}$ na base do tubo da corola; pistilo 2,4-2,6 cm compr.; ovário 3,3 × 0,8$1 \mathrm{~mm}$, oblongo, lepidoto; óvulos 2-seriados; disco nectarífero 1,3-1,5 × 2,0-2,7 mm, transversalmente elíptico. Cápsula 16,8-20,2 × 1,8-1,9 cm, linear, tomentosa, base cuneada, ápice agudo a acuminado; sementes 1,4-1,6 × 2,4-2,6 cm, orbiculares, alas hialinas, membranáceas nas extremidades.

Material examinado: Estrada Buíque-Catimbau, 10.X.1995, fl., L.S. Figuêiredo et al. 233 (PEUFR); 10.X.1995, fl., K. Andrade et al. 235 (PEUFR); Fazenda Laranjeiras, 7.XII.1996, fr., A.P.S. Gomes 379 (PEUFR). Material adicional: BRASIL. PERNAMBUCO: Ouricuri, Fazenda Estaca, 5.VI.1984, G. Costa-Lima 10 (IPA). Serra Talhada, 12.VII.1990, R. Pereira (IPA).

Fridericia dichotoma ocorre na Argentina, Equador, Panamá, Belize, Bolívia (Parker \& Bailey 1991), Guiana, Guiana Francesa, Suriname, Venezuela, México e Peru (Bridgewater et al. 2006; Gentry 1973, 1982; Gentry \& Grose 2007;
Macbride 1961). No Brasil, é encontrada no Ceará, Goiás, Minas Gerais, Pernambuco, Rio Grande do Sul e Santa Catarina (Sales et al. 1998; Sandwith \& Hunt 1974). No PNVC ocorre em áreas de Caatinga, predominantemente em solos arenosos. Reconhecida pelos ramos estriados com lenticelas salientes, abundantes, folhas 3-folioladas, folíolos membranáceos com a face inferior tomentosa e superior velutina, inflorescências em tirsos multifloros, cálice com o bordo truncado e corola lilás. Na área de estudo floresce em outubro e frutifica em dezembro.

4. Fridericia limae (A.H. Gentry) L.G. Lohmann, Ann Missouri Bot. Gard. 2006, in press.

Fig. 2d-h

Liana; ramos cilíndricos, estrias transversais, glabros, lenticelas salientes; pseudoestípulas conspícuas; folhas 2-folioladas; pecíolo 1,44,6 cm compr., cilíndrico, glabro; peciólulo 0,4-1,2 cm compr.; folíolos 1,9-7,5 × 1,1-4,3 $\mathrm{cm}$, glabros, fortemente cartáceos, oblongos a elípticos, base cordada, ápice arredondado a agudo, margem plana, com glândulas escuras na face abaxial, broquidódroma. Inflorescência glabra, axilar, tirso, pauciflora, glabra; cálice tubular, diminutamente 5-denticulado, 0,6-0,9 $\times$ 0,4-0,8 cm, presença de glândulas na base, ápice ciliado; corola tubular-campanulada, tricomas puberulentos, branca, tubo $4,1 \times 1 \mathrm{~cm}$ na região mediana; estames com anteras 3-3,5 $\times 1 \mathrm{~mm}$, divaricadas; filetes longos $1,9 \mathrm{~cm}$ compr., filetes curtos 1,4 cm compr., inseridos $5 \mathrm{~mm}$ na base do tubo da corola; pistilo 2,7 cm compr.; ovário $2 \times$ $0,8 \mathrm{~mm}$, cilíndrico, lepidoto, óvulos 2-seriados; disco nectarífero $1,2 \times 2,5 \mathrm{~mm}$, transversalmente elíptico. Cápsula 15,6 × 1,8 cm, oblongo-linear, glabra, base cuneada, ápice agudo; sementes 2,5$2,7 \times 2,5-2,7 \mathrm{~cm}$, orbiculares, alas amarronzadas, membranáceas nas extremidades.

Material examinado: Estrada Buíque-Catimbau, 17.III.1995, M.J.N. Rodal et al. 510 (PEUFR); Estrada para a casa do artesão, 18.I.2012, L.S.D. Oliveira 201 (PEUFR), T.M.S. Melo 240 (PEUFR); Fazenda Laranjeiras, 20.III.1995, fr., A. Laurênio et al. 63 (PEUFR); 20.III.1995, fl., L. Figueiredo et al. 63. (PEUFR); Sítio Pititi, 3.III.1997, fl., A. Laurênio et al. 423 (PEUFR).

Material adicional: BRASIL. PERNAMBUCO: Arcoverde, 13.IX.2006, fr., A. Bocage1159 (IPA). Araripina, 4.IV.1963, fl. e fr., Andrade-Lima 63159 (IPA).

Espécie endêmica da Caatinga nordestina encontrada na Bahia, Ceará e Pernambuco (Gentry 1980). No PNVC, é facilmente encontrada 


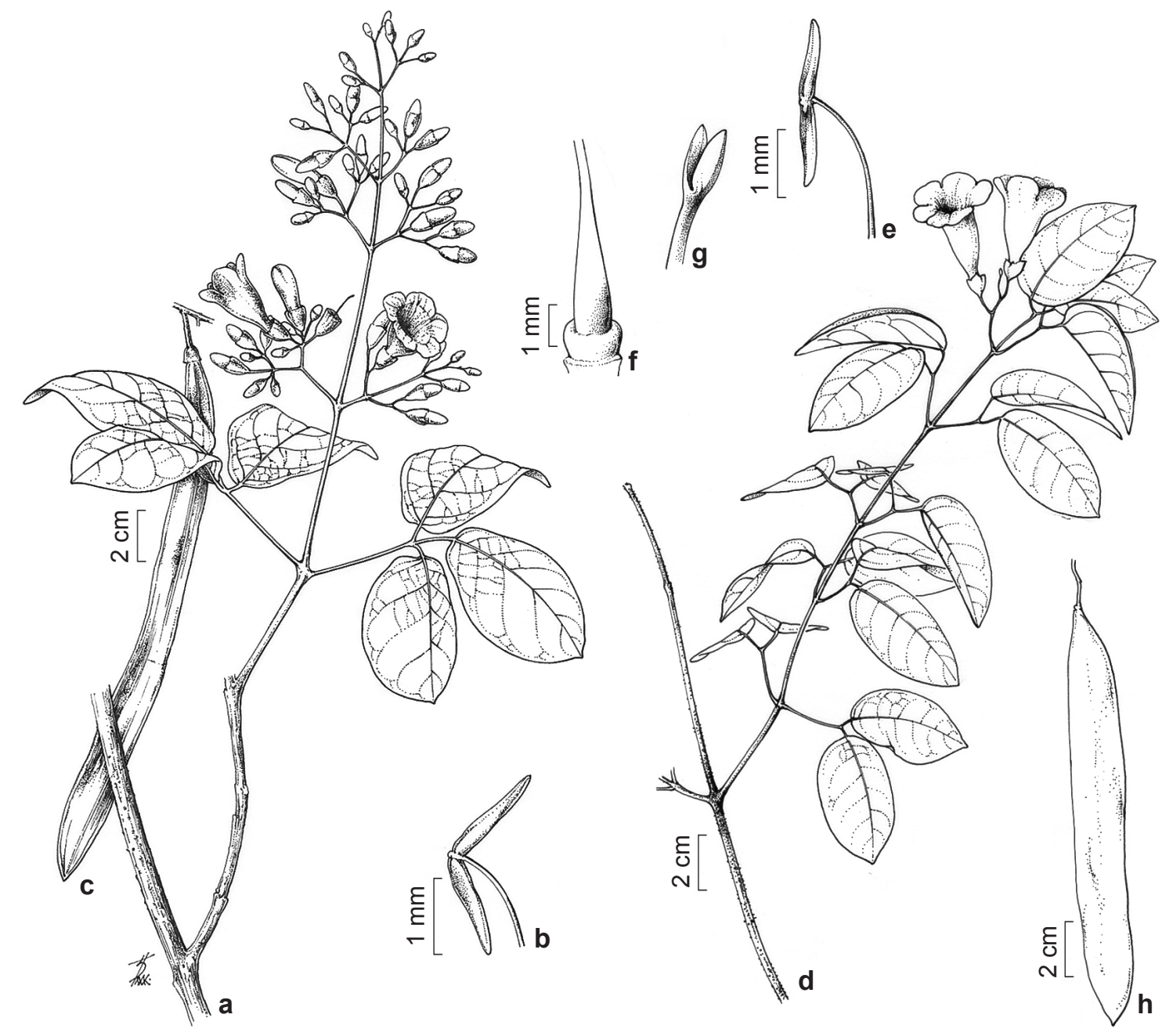

Figura 2 - a-c. Fridericia dichotoma (Jacq.) L.G. Lohmann - a. ramo florido; b. detalhe das anteras divaricadas; c. cápsula. (a-c A.P.S. Gomes 379). d-h. Fridericia limae (A.H. Gentry) L.G. Lohmann - d. ramo florido; e. detalhe das anteras divaricadas; f. detalhe do disco nectarífero e do ovário; g. detalhe do estigma bífido; h. cápsula (d-h MJ.N. Rodal et al. 510 ). Figure 2 - a-c. Fridericia dichotoma (Jacq.) L.G. Lohmann - a. flowery branch; b. detail of anthers divaricate; c. capsule. (a-c A.P.S. Gomes 379). d-h. Fridericia limae (A.H. Gentry) L.G. Lohmann - d. flowery branch; e. detail of anthers divaricate; f. detail of the nectariferous disk and ovary; g. detail of stigma bifid; h. capsule. (d-h MJ.N. Rodal et al. 510).

em vegetação de Caatinga arbustiva, sobre solos arenosos, nas vertentes a sotavento da Chapada de São José. Distingue-se de $F$. dichotoma por apresentar folíolos fortemente cartáceos e glabros, inflorescências em tirsos paucifloros, flores com corola lilás e cálice com bordo diminutamente 5-denticulado. Floresce de março a maio, frutificando em maio.

Handroanthus Mattos, Loefgrenia 50: 2. 1970.

Predominantemente árvores, às vezes arbustos; pseudoestípula ausente; folhas 5-9(3) folioladas, folíolos elípticos a ovados. Inflorescência terminal, dicotomicamente ramificada; cálice campanulado, coriáceo, 5-dentado; corola tubularinfudibuliforme ou tubular-campanulada, amarela ou magenta; estames didínamos, anteras divaricadas; estaminódio reduzido; ovário cônico a linearoblongo; óvulos 2-seriados em cada lóculo. Cápsula linear a cilíndrica, lisa a levemente costada, glabra a dispersamente lepidoto a pubescente; sementes aladas, bilabiadas.

O gênero é composto por 30 espécies distribuídas desde a América Central até a América do Sul, com uma espécie registrada para as Antilhas (Grose \& Olmstead 2007b). 
5. Handroanthus chrysotrichus (Martius ex DC.) Mattos, Loefgrenia 50: 4. $1970 . \quad$ Fig. 3a-b

Árvore 8-9 m; ramos cilíndricos, canaliculados, estriados, glabrescentes a estrelados; folhas digitadas, 5-folioladas, anisófilas; pecíolo 3,2-8 cm compr., anguloso, estrelado-tomentoso; peciólulo 1-3,1 cm compr.; folíolos terminais $5-8,2 \times 3,7-5,9 \mathrm{~cm}$, folíolos intermediários 4-10,5 × 1,5-6 cm, folíolos basais $2-6,3 \times 1,2-3,8 \mathrm{~cm}$, face abaxial estrelada, face adaxial glabra a glabrescente, cartáceos, obovais a ovado-elípticos, base atenuada à arredondada, ápice agudo a arredondado, margem inteira, na parte superior denteada, broquidódroma. Inflorescência terminal, panícula, pauciflora; cálice 1-1,5 × 5-7 mm, tubular, diminutamente 4-denticulado, estrelado-tomentoso, dourado; corola internamente glabra, externamente glabrescente, amarela, tubo $6-7,1 \times 0,8-1,5$ $\mathrm{cm}$ na região mediana, lobos $1,5-1,9 \times 0,8-1$ $\mathrm{cm}$, arredondados, ápice apiculado; estames didínamos, com anteras de 3-3,5 × $1 \mathrm{~mm}$, divaricadas; filetes longos $2 \mathrm{~cm}$ compr., filetes curtos $1,7 \mathrm{~cm}$ compr., estaminódio $1,7 \mathrm{~cm}$ compr., inseridos a $9 \mathrm{~mm}$ da base do tubo da corola; pistilo 2,9 cm compr.; ovário $3 \times 1,5 \mathrm{~mm}$, linear, glabro a lepidoto; disco nectarífero $1 \mathrm{~mm} \times 2,5 \mathrm{~mm}$, cupuliforme. Cápsula não observada.

Material examinado: Fazenda Esmeralda, 18.X.1994, fl., M.J.N. Rodal et al. 423 (PEUFR); Serra do Catimbau, complexo caatinga-campo, 18.X.1994, fl., M.F. Sales 790 (PEUFR); Vale do Catimbau, 23.III.2012, L.D.S. Oliveira 202 (PEUFR).

Distribui-se desde o Nordeste até o Sul do Brasil (Oliveira et al. 2008). No PNVC, ocorre no complexo Caatinga-campo, em área devastada, com relevo ondulado e em vegetação perenifólia arbustiva, situada na encosta, em solos arenosos violáceos. Caracteriza-se por apresentar ramos com tricomas estrelados, folhas digitadas, 5-folíolos, anisófilos, cálice tubular, didiminutamente 4-denticulado, estreladotomentoso, dourado e corola amarela. Floresce em outubro.

6. Handroanthus impetiginosus (Mart. ex DC.) Mattos, Loefgrenia 50: 2. $1970 . \quad$ Fig. 3c-d

Árvore 8-10 m; ramos cilíndricos, estriados, glabros, lenticelas abundantes; folhas digitadas, 5-foliolada, anisófilas; pecíolo 3,1-7,3 cm compr., cilíndrico, glabro; peciólulo $0,5-2,5$ $\mathrm{cm}$; folíolos terminais $4-10,6 \times 1,9-5,5 \mathrm{~cm}$, folíolos intermediários 5,2-9 × 2,3-3,7 cm, folíolos basais 2,3-6,2 × 1,4-3,2 cm, face abaxial glabra, pilosa na região de inserção das nervuras laterais com a central, face adaxial glabra, membranáceos a cartáceos, elípticos a ovais, base arredondada, ápice agudo a caudado, margem inteira, broquidódroma. Inflorescência terminal, panícula, multiflora; botões $1,3-2,4$ $\times$ 4-6 cm, ápice arredondado; cálice 5-6 × 3-5 $\mathrm{mm}$, campanulado, 4-denticulado, glabro; corola tubular-campanulada, internamente puberulenta, externamente pubescente, rósea a lilás, tubo 4-5,6 $\times 1,3-1,5 \mathrm{~cm}$ na região mediana, lobos $1,1-1,5$ $\times 1-1,6 \mathrm{~cm}$, arredondados; estames com anteras de $4-5 \times 1,5 \mathrm{~mm}$, divaricadas; filetes longos $1,2-2 \mathrm{~cm}$ compr., filetes curtos $0,8-1,3 \mathrm{~cm}$ compr., estaminódio 6-7 mm compr., inseridos 7-9 $\mathrm{mm}$ na base do tubo da corola; pistilo 3-3,5 cm compr.; ovário 3-3,5 × 0,8-1 mm, ovóide-elipsóide, glabro a lepidoto; disco nectarífero $1 \mathrm{~mm} \times 1,3-2$ $\mathrm{mm}$, cupuliforme. Cápsula 11-18,9 × 0,7-1,1 $\mathrm{cm}$, linear, glabra, base atenuada, ápice agudo; sementes $1,1-1,4 \times 8-9 \mathrm{~mm}$, suborbiculares, alas membranáceas.

Material examinado: Catimbau, 6.XII.1996, fr., A.P.S. Gomes et al. 360 (PEUFR); 3.V.2012, J.S. Santos 242 (PEUFR); 5.V.2012, J. S. Santos 241 (PEUFR); L.S.D. Oliveira 189 (PEUFR); Estrada para a casa do artesão, 19.V.2012, fr., T.M.S. Melo 206 (PEUFR); fl., T.M.S. Melo 266 ; Estrada Buíque-Catimbau, 22.IX.1995, fl., L.S. Figueirêdo et al. 205 (PEUFR); 9.X.1995, fl., L.S. Figueirêdo et al. $220 \mathrm{~b}$ (PEUFR); Trilha das Torres, 17.X.1994, fl., M.J.N. Rodal 411 (PEUFR); Serra do Catimbau, 3.VIII.2011, fl., L. Lima 50 (PEUFR); L.D.S. Oliveira 203 (PEUFR).

Ocorre na Argentina, Bolívia, Colômbia, Equador, Guiana Francesa, Paraguai, Peru, Suriname, Trinidad e Tobago e Venezuela (Castellanos et al. 2008). No Brasil, é encontrada nas Regiões Nordeste e Sudeste (Gemaque et al. 2002). No PNVC, a espécie distribui-se no complexo Caatinga-campo, em vegetação arbustiva perenifófia densa, situada na encosta e em solos arenosos violáceos. Distingui-se de $H$. chrysotrichus por apresentar ramos glabros, folíolos elípticos a ovais, cálice campanulado, 4-denticulado, glabro e corola lilás a rósea. Floresce em abril.

Jacaranda Juss., Gen. P1.: 138. 1789.

Árvores ou arvoretas, às vezes arbustos ou subarbustos; folhas geralmente bipinadas, ocasionalmente pinadas, raro simples; raque comumente subalada a alada, canaliculada. Inflorescência axilar ou terminal, racemo ou 


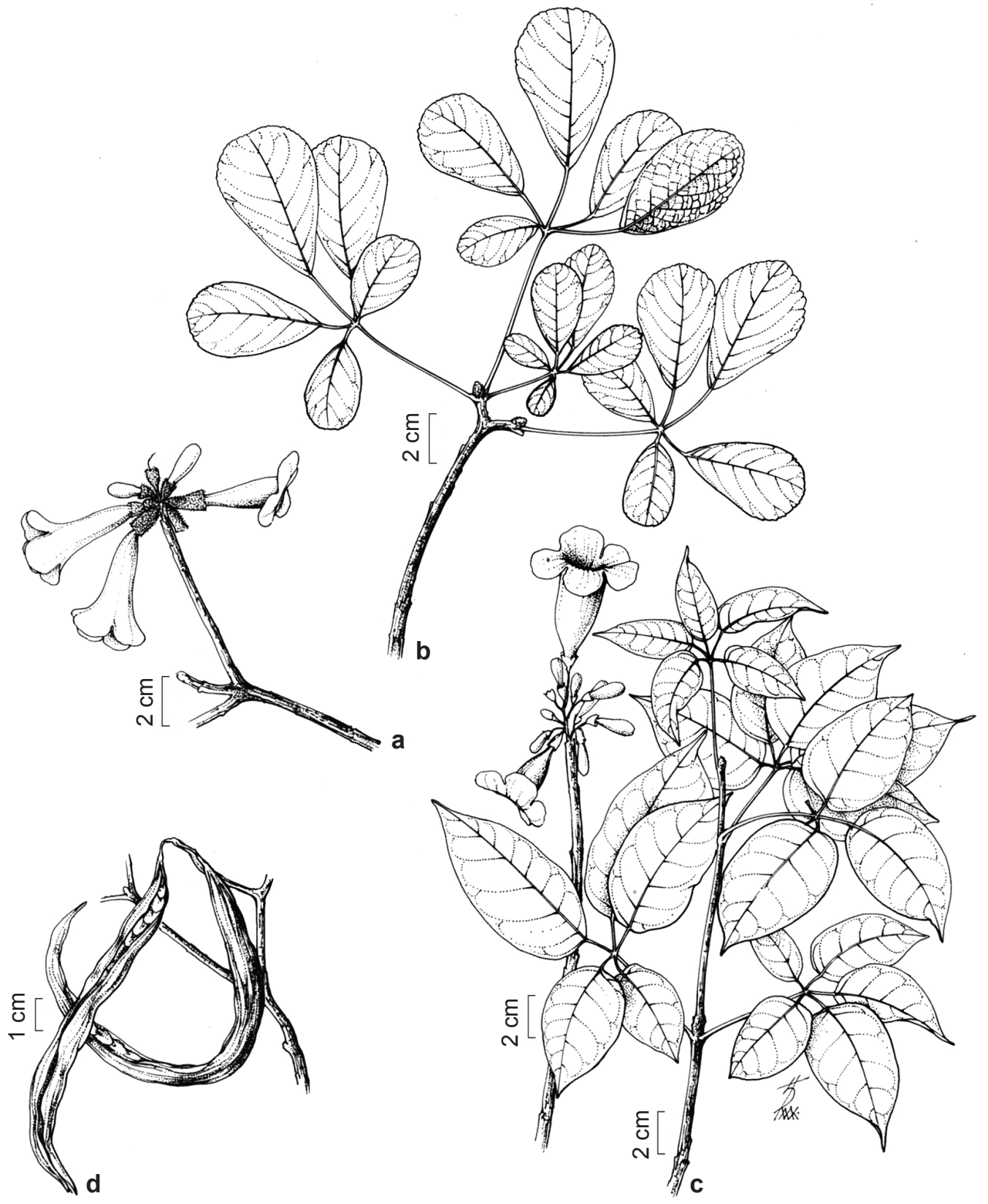

Figura 3 - a-b. Handroanthus chrysotrichus (Martius ex DC.) Mattos - a. ramo florido; b. ramo estéril com folhas digitadas. (a-b M.J.N. Rodal et al. 423). c-d. Handroanthus impetiginosus (Mart. ex DC.) Mattos - c. ramo florido; d. cápsula. (c-d L.S. Figueirêdo et al. 220b).

Figure 3 - a-b. Handroanthus chrysotrichus (Martius ex DC.) Mattos - a. flowery branch; b. sterile branch with leaves digitadas. (a-b M.J.N. Rodal et al. 423). c-d. Handroanthus impetiginosus (Mart. ex DC.) Mattos - c. flowery branch; d. capsule. (c-d L.S. Figueirêdo et al. $220 b$ ).

tirso; cálice campanulado a cupuliforme, 5-lobado ou 5-denticulado, lacínios com ápice agudo a acuminado, arredondado ou truncado; corola tubular-infundibuliforme ou tubular-campanulada, glabra a pubescente, azul, arroxeada, lilás ou vinácea, raramente branca; anteras bitecas ou monotecas, glabras, estaminódio alongado, excedendo os estames, com tricoma glandular; ovário ovóide, glabro ou pubescente; óvulos 2-8-seriados por lóculo; disco nectarífero 
anular. Cápsula loculicida, oblonga, elipsóide ou obovóide, lenhosa, glabra ou lepidota, margem geralmente ondulada; sementes com alas membranáceas.

Gênero com cerca de 55 espécies com distribuição na América tropical (Olmstead et al. 2009).

\section{Jacaranda rugosa A. H. Gentry, Fl. Neotrop.} Monogr. 25(2): 102. 1992.

Fig. $4 \mathrm{a}-\mathrm{b}$

Arbusto ca $1,5 \mathrm{~m}$; ramos cilíndricos, estriados, híspidos; pseudoestípulas inconspícuas, às vezes ausentes; folhas pinadas, $7-9$ folíolos por pina; pecíolo 1,1-3,6 cm compr., cilíndrico, glabro, com glândulas na base e no ápice; peciólulo 2-4 mm compr.; folíolos 1-5,7 × 1-3 cm, face abaxial híspida, face adaxial hirsuta, cartáceos, elípticos a ovais, base cuneada a arredondada, ápice agudo a emarginado, margem inteira, broquidódroma. Inflorescência axilar, racemo, multiflora, botões $1,1-2,1 \times 0,5-1,2 \mathrm{~cm}$, ápice arredondado; cálice 5-6 $\times 3-4 \mathrm{~mm}$, tubular, glandular, híspido na base; corola tubular-campanulada, internamente glabra, externamente glandular, lilás, tubo 3,2-4 × 1-1,8 $\mathrm{cm}$ na região mediana, lobos $8-9 \times 0,8-1 \mathrm{~cm}$, arredondados, estames didínamos; anteras 2,5-2,5 $\times 1 \mathrm{~mm}$, divaricadas; filetes longos $2,3 \mathrm{~cm}$ compr., filetes curtos $1,8 \mathrm{~cm}$ compr., estaminódio $2,7 \mathrm{~cm}$ compr., com tricomas glandulares, inseridos $8 \mathrm{~mm}$ na base do tubo da corola; pistilo 3,2 cm compr.; ovário $3 \times 2 \mathrm{~mm}$, ovóide a elipsóide, glabro; óvulos 2-seriados; disco nectarífero 1,3 $32 \mathrm{~mm}$, anular. Cápsula 3,2-5,5 × 2,9-3 cm, elipsóide, escabrosa, base arredondada, ápice apiculado; sementes suborbiculares, alas amarronzadas, membranáceas.

Material examinado: Estrada Buíque-Catimbau, fl., M.J.N. Rodal 429 (PEUFR); Catimbau, trilha para o Canyon, 3.V.2012, fr., S.M.A. Souza 89 (PEUFR); 4.V.2012, fr., T.M.S. Melo 277 (PEUFR); Serra do Catimbau, 19.VI.1994, fl. e fr., A.M. Miranda et al. 1794 (PEUFR); 1.VIII.2011, fr., L. Lima 107 (PEUFR); Trilha das Torres, complexo Caatinga-campo, 19.VIII.1994, fl., M.F. Sales et al 410 (PEUFR).

Jaracanda rugosa é uma espécie rara (Lohmann \& Silva-Castro 2009) restrita, até o momento, ao município de Buíque, e encontrada em solos arenosos (Gentry 1992; Sales et al. 1998). É reconhecida pelo porte arbustivo, folhas pinadas com 7-9 folíolos e estaminódio com tricoma glandular ultrapassando o comprimento dos estames. Floresce de junho a agosto, frutificando de maio a agosto.
Mansoa DC., Bibl. Univ. Genève. II, 17: 128. 1838.

Lianas; pseudoestípula presente; folhas 3-folioladas, com gavinha terminal, trífida, às vezes ausente. Inflorescência geralmente axilar, tirso; cálice 5-dentado, algumas vezes bilabiado; corola infundibuliforme; estames inclusos; anteras divaricadas, glabras; ovário glabro ou lepidoto, disco nectarífero cupular. Cápsula oblonga, achatada; sementes com alas curtas, hialinas, membranáceas.

Gênero com 12 espécies encontrado do México a Argentina (Lohmann \& Ulloa 2011).

8. Mansoa difficilis (Cham.) Bureau \& K.Schum, Fl. Bras. 8(2): 201-202. $1896 . \quad$ Fig. 4c-f

Liana; ramos cilíndricos, com estrias transversais; pseudoestípulas conspícuas; folhas 3-folioladas; pecíolo 0,4-1 cm compr., cilíndrico, glabro; peciólulo 2-5 $\mathrm{mm}$ compr.; folíolos 2,2-5,3 cm $\times 0,9-2,3$ $\mathrm{cm}$, glabros, membranáceos, ovais a elípticos, base arredondada a discretamente cordada, ápice agudo, margem inteira, broquidódroma. Inflorescência axilar ou terminal, tirso, pauciflora; botões $0,5-1,6 \times 1,3-1,5 \mathrm{~cm}$, ápice arredondado; cálice tubular, 5-6-denticulado, glabro; corola infundibuliforme, glabra, lilás, tubo 3,5-4 × 1-1,5 cm na região mediana, lobos $1,8-2 \times 1,3-1,5 \mathrm{~cm}$, ápice arredondado; estames com anteras de 3-4,1 × $1 \mathrm{~mm}$, divaricadas; filetes longos 2,3 cm compr., filetes curtos $1,6 \mathrm{~cm}$ compr., estaminódio 3-4,5 mm compr., inseridos 9-10 mm na base do tubo da corola; pistilo 3-3,4 cm compr.; ovário 3,1-3,5 × $1 \mathrm{~mm}$, oblongocilíndrico, lepidoto; óvulos 2-seriados; disco nectarífero $1,1 \times 1,5-1,8 \mathrm{~mm}$, transversalmente elíptico. Cápsula não observada.

Material examinado: Fazenda Laranjeiras, 20.V.1995, fl., E. Inácio et al. 56 (PEUFR); 16.VI.1995, f1., $L$. Figueirêdo 81 (PEUFR); Estrada para a casa do artesão, 18.V.2012, fl., T.M.S. Melo 174 (PEUFR).

Espécie encontrada nas Regiões Norte (Pará), Nordeste (Bahia, Maranhão, Paraíba e Pernambuco), em todo o Sudeste e toda Região Sul (Lohmann 2013). No PNVC, ocorre em áreas de Caatinga, em solos arenosos e profundos, nas vertentes a sotavento da Chapada de São José. É reconhecida pelas folhas 3 -folioladas, com gavinha terminal trífida, cálice tubular, 5-6-denticulado, glabro e corola tubular-infundibuliforme, glabra. Floresce em maio. 


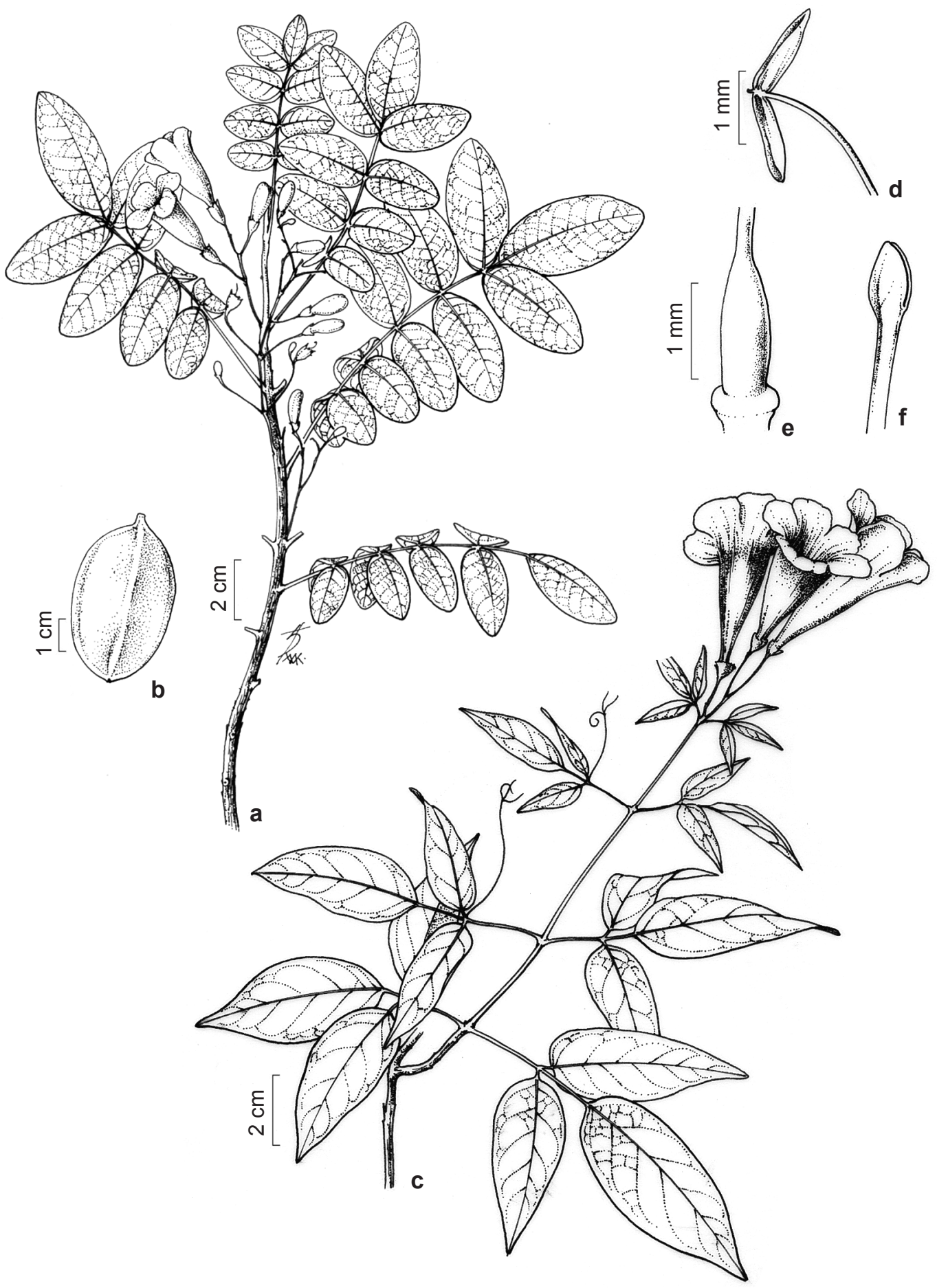

Figura 4 -a-b. Jacaranda rugosa A. H. Gentry - a. ramo florido; b. cápsula. (a-b M.F. Sales et al 410). c-f. Mansoa difficilis (Cham.) Bureau \& K. Schum - c. ramo florido; d. anteras divaricadas. e. detalhe do disco nectarífero e do ovário; f. detalhe do estigma bífido. (c-f L. Figueirêdo 81)

Figure 4 - a-b. Jacaranda rugosa A. H. Gentry - a. flowery branch; b. capsule. (a-b M.F. Sales et al 410). c-f. Mansoa difficilis (Cham.) Bureau \& K. Schum - c. flowery branch; d. divaricates anthers. e. detail of the nectariferous disk and ovary; f. detail of stigma bifid. (c-f L. Figueirêdo 81). 
Pyrostegia C. Presl, Abh. Königl. Böhm. Ges. Wiss., ser. 5 3: 523. 1845.

Lianas; ramos angulosos; pseudoestípulas inconspícuas; folhas 2(3)-folioladas, gavinha terminal, geralmente trífida. Inflorescência axilar ou terminal, panícula; cálice tubular, truncado, 5-denticulado, ligeiramente lepidoto; corola estreitamente tubular-infundibuliforme, laranja; estames exsertos, anteras glabras; ovário lepidoto; disco nectarífero presente. Cápsula linear, achatada, valvas paralelas ao septo; sementes bialadas, alas com a margem hialina a amarronzadas.

Gênero com duas espécies distribuídas desde o México à Argentina (Lohmann \& Ulloa 2011).

9. Pyrostegia venusta (Ker. Gawl.) Miers, Proc. Roy. Hort. Soc. London 3: 188. $1863 . \quad$ Fig. 5a-e

Liana; ramos angulosos, com estrias transversais; pseudoestípulas filiformes, $0,2-0,7 \mathrm{~cm}$ compr.; folhas 2-folioladas, gavinha terminal, trífida, pecíolo $0,5-3 \mathrm{~cm}$ compr., anguloso, puberulento; peciólulo 2-8 $\mathrm{mm}$ compr.; folíolos 2,1-6,7 $\mathrm{cm} \times$ 1,7-3,9 cm, glabrescentes, cartáceos, ovais, base arredondada, ápice agudo a acuminado, margem inteira, plana, broquidódroma. Inflorescência axilar, panícula, multiflora; botões 5,5-2,6 $\mathrm{mm} \times 4-6 \mathrm{~mm}$, ápice agudo; cálice campanulado, 0,4-0,5 ×0,6 cm, 5-denticulado, ápice ciliado; corola estreitamente tubular-infundibuliforme, glabra, laranja, tubo 5,8-6,4 × 7-9 mm, na região mediana, lobos 1,4-1,7 × 4-5 mm, oblongo-lanceolados; estames exsertos; anteras 5-6 6 1,5 mm, paralelas; filetes longos 3,6-5,4 cm compr., filetes curtos $3-5 \mathrm{~cm}$ compr.; estaminódio 1,5-2 mm compr., inseridos 2,5-3 $\mathrm{mm}$ na base do tubo da corola; pistilo 8,2 cm compr.; ovário $6 \times 0,8-1 \mathrm{~mm}$, linear, lepidoto; óvulos 2-seriados; disco nectarífero $2 \times 1,5 \mathrm{~mm}$, cupular. Cápsula 4,7-34 × 0,5-1,1 cm, linear, glabra a lepidota, base e ápice acuminados; sementes com alas membranáceas nas extremidades, amarronzadas. Material examinado: Estrada Buíque-Catimbau, 10.X.1995, fl., K. Andrade et al. 229 (PEUFR); 21.IX.1995, fl., K. Andrade et al. 214 (PEUFR); 24.IX.2004, fl., A.M. Miranda 4487 (HST); Serra do Catimbau, 17.IX.1994, fl., M.F. Sales 382 (PEUFR); Sítio Breu, 9.XII.2006, fl., E.A. Rocha 1501 (IPA); Tribo Kapinawá, 12.XII.1994, fr., R.S. Pinho 47 (PEUFR); Vale do Catimbau, 10.II.1994, W. Forstrentes 1612 (IPA).

Pyrostegia venusta é encontrada na Argentina, Bolívia, Brasil e Paraguai (Sandwih \& Hunt 1974). No Brasil, ocorre desde o Piauí até o Rio Grande do Sul (Pool 2008). No PNVC, é encontrada em vegetação perenifólia arbustiva, rupestre.
Distingue-se das demais espécies por apresentar flores laranjas, estames exsertos do tubo da corola com anteras paralelas, cápsula linear, glabra a lepidota, com ca 4,7-34 cm compr. Floresce de setembro a outubro.

Tabebuia Gomes ex DC., Biblioth. Universelle Geneve ser 2. 17: 130-131. 1838.

Árvores ou arbustos; folhas digitadas, folíolos variáveis em tamanho. Inflorescência axilar ou terminal, tirso curto, surgindo geralmente antes das folhas; cálice campanulado ou tubular, geralmente 5-denteado, às vezes bilabiado; corola infundibuliforme, amarela, branca ou lilás; estaminódio reduzido, glabro ou indumentado na altura da inserção dos estames; ovário oblongo, lepidoto ou glabro; óvulos 2-8-seriados por lóculo; disco nectarífero anular. Cápsula loculicida, linear-cilíndrica, coriácea, pubescente, lisa, margem plana; sementes com alas membranáceas.

Tabebuia compreende cerca de 100 espécies, distribuídas desde os Estados Unidos até a Argentina (Grose \& Olmstead 2007b). No Brasil, é encontrado nos domínios da Amazônia, Caatinga, Cerrado, Mata Atlântica e Pantanal (Lohmann 2013).

10. Tabebuia aurea (Silva Manso) Benth. \& Hook.f. ex S.Moore, Trans. Linn. Soc. London, Bot. 4: 423. 1895.

Fig. $5 \mathrm{f}-\mathrm{h}$

Árvore 6-9 m; ramos cilíndricos, estriados, lepidotos, lenticelas abundantes; pseudoestípula ausente; folhas digitadas, 5-7-folíolos, anisófilos; pecíolo 3-7 cm compr., canaliculado, lepidoto; peciólulo 1-3,7 cm compr., folíolos terminais 10-13 × 2,2 cm, folíolos intermediários 7,8-11,9 $\mathrm{cm} \times 1,9-2,6 \mathrm{~cm}$, folíolos basais 3,9-7 × 1,5-2 cm, face abaxial lepidota, face adaxial glabra, cartáceos, oblongos a oblongo-ovados, base oblíqua, ápice agudo, margem inteira, broquidódroma. Inflorescência terminal, panícula, multiflora; botões $1 \times 0,5 \mathrm{~cm}$, ápice arredondado; cálice 1,2-1,5 × 5-7 $\mathrm{mm}$, campanulado, 5-denteado, lepidoto; corola tubular-campanulada, internamente pubérula, externamente lepidota, amarela, tubo 4,5 × 0,9-1,3 $\mathrm{cm}$ na região mediana, lobos $1-1,4 \times 0,9-1,4 \mathrm{~cm}$, arredondados; estames didínamos; anteras 3,5-4× $1,5 \mathrm{~mm}$, divaricadas; filetes longos $2 \mathrm{~cm}$ compr., filetes curtos $1,3 \mathrm{~cm}$ compr., estaminódio $2 \mathrm{~mm}$ compr., inseridos a $1,1 \mathrm{~cm}$ na da base do tubo da corola; pistilo 3,5-4 cm compr.; ovário $3 \times 1,5 \mathrm{~mm}$, ovóide-elipsóide, lepidoto; disco nectarífero $2 \mathrm{~mm}$ 


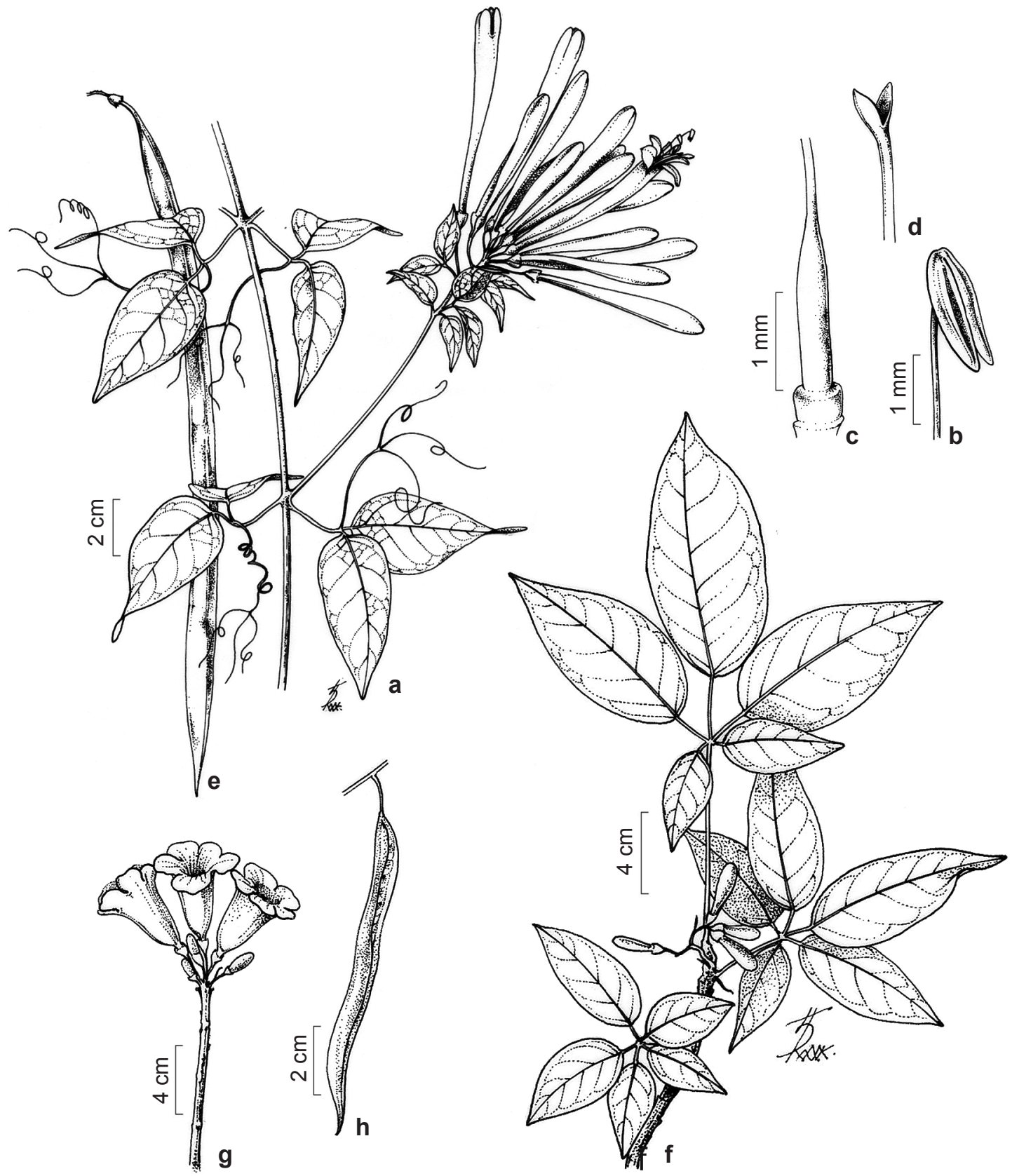

Figura 5 - a-e. Pyrostegia venusta (Ker Gawl.) Miers - a. ramo florido; b. anteras com tecas paralelas; c. detalhe do disco nectarífero e do ovário; d. estigma bífido; e. cápsula. (a-e K. Andrade et al. 229). f-h. Tabebuia aurea (Silva Manso) Benth. \& Hook. f. ex S. Moore - f. ramo florido; g. inflorescência; h. cápsula. (f-h K.C. Costa 179).

Figure 5 - a-e. Pyrostegia venusta (Ker Gawl.) Miers - a. flowery branch; b. anthers with thecae parallel; c. detail of the nectariferous disk and ovary; d. stigma bifid; e. capsule. (a-e K. Andrade et al. 229) f-h. Tabebuia aurea (Silva Manso) Benth. \& Hook. f. ex S. Moore - f. flowery branch; g. inflorescence; h.capsule. (f-h K.C. Costa 179)

$\times 2,5 \mathrm{~mm}$, cupuliforme. Cápsula $10 \mathrm{~cm} \times 7 \mathrm{~mm}$, linear, lepidota, base atenuada, ápice acuminado; sementes $1,1-1,4 \times 8-9 \mathrm{~cm}$, suborbiculares, alas membranáceas.
Material selecionado: BRASIL. PERNAMBUCO: Custódia, 18.X.1995, fl., fr., A.M. Miranda 2298 (HST). Floresta, 27.IX.1971, fl., F.B. Ramalho 25 (IPA). Ouricuri, 9.XII.1968, fl., G.H. Carvalho 74 (IPA). 
Petrolândia, 29.X.1996, fl., A.M. Miranda 2550 (HST). Venturosa, Parque Pedra Furada. 1999, fl., K.C. Costa 179 (PEUFR).

Tabebuia aurea distribui-se do Peru ao Paraguai (Lohmann \& Ulloa 2011). No Brasil, ocorre em todos os estados, com exceção do Acre, Rondônia e Roraima (Norte), Rio de Janeiro e Espírito Santo (Sudeste), Rio Grande do Sul e Santa Catarina (Sul) (Lohmann 2013). No PNVC, é encontrada em áreas de Caatinga. Caracteriza-se por apresentar ramos, pecíolos, folhas, flores e frutos providos de tricomas lepidotos, folíolos oblongos a oblongo-ovais e cálice campanulado, 5-denteado. Floresce em abril.

\section{Agradecimentos}

As autoras agradecem ao Conselho Nacional Científico e Tecnológico (CNPq) o apoio financeiro, à Universidade Federal Rural de Pernambuco (UFRPE) o apoio acadêmico e aos curadores dos herbários, em especial a Dra. Elizabeth Bandeira Pedrosa (PEUFR), o empréstimo das exsicatas.

\section{Referências}

Angiosperm Phylogeny Group III. 2009. An update of the Angiosperm Phylogeny Group classification for the orders and families of flowering plants: APG III. Botanical Journal of the Linnean Society 161: 105-121.

Assis, M.A.; Scudeller, V.V. \& Semir, J. 2000. Flórula Fanerogâmica da planície litorânea de Picinguaba, Ubatuba, São Paulo, Brasil: Bignoniaceae Juss. Naturalia 25: 77-103.

Bridgewater, S.G.M.; Harris, D.J.; Whitefoord, C.; Monro, A.K.; Penn, M.G.; Sutton, D.A.; Sayer, B.; Adams, B.; Balick, M.J.; Atha, D.H.; Solomon, J. \& Holst, B.K. 2006. A preliminary checklist of the vascular plants of Chiquibul Forest, Belize. Edinburgh Journal of Botany 63: 269-321.

Brummit, R.F. \& Powell, C.E. 1992. Authors of plant names. Royal Botanical Gardens, Kew. 732p.

Bureau, E. \& Schumann, K. 1896-1897. Bignoniaceae. In: Martius, C.F.P. von; Eichler, A.W. \& Urban, I. Flora brasiliensis. Munchen, Wien, Leipzig. Vol 8. Pp. 1-451.

Castellanos, J.R.G.; Pietro, J.M. \& Heinrich, M. 2008. Red Lapacho (Tabebuia impetiginosa) - A global ethnopharmacological commodity? Journal of Ethnopharmacology 121: 1-13.

Chen, S.; Guan, K.; Zhou, Z.; Olmstead, R.G. \& Cronk, Q. 2005. Molecular phylogeny of Incarvillea (Bignoniaceae) based on ITS and trnL-F sequences. American Journal of Botany 92: 625-633.

DOU - Diário Oficial da União. 2002. Decreto 913/12 de 13 de dezembro de 2002. N. 242. 16 de dezembro de 2002. Pp. 13-14.
Ferreira, R.R. 2009. Ecoturismo no município de Buíque - Pernambuco: avaliação crítico-reflexiva à luz desenvolvimento local sustentável. Dissertação de Mestrado. Universidade de Pernambuco, Recife. 140p.

Figueirêdo, L.S; Rodal, M.J.N \& Melo, A.L. 2000. Florística e fitossociologia da vegetação caducifólia espinhosa arbustiva no município de Buíque, Pernambuco. Naturalia 25: 205-224.

Gemaque, R.C.R.; Davide, A.C. \& Faria, J.M.R. 2002. Indicadores de maturidade fisiológica de sementes de ipê-roxo (Tabebuia impetiginosa (Mart.) Standl.). Cerne 8: 84-91.

Gentry, A.H. 1973. Flora of Panamá: Bignoniaceae. Annals of the Missouri Botanical Garden 60: 573780 .

Gentry, A.H. 1980. Bignoniaceae Part I: Tribe Crescentieae and Tourrettieae. Flora Neotropica 25: 1-117.

Gentry, A.H. 1982. Bignoniaceae - Flora de Veracruz. Instituto Nacional de Investigaciones sobre Recursos Bióticos 24: 1-221.

Gentry, A.H. 1992. Bignoniaceae Part II: Tribe Tecomeae. Flora Neotropica 25: 1-358.

Gentry, A.H. 1995. Bignoniaceae. In: Stannard, B.L. (ed.). Flora of Pico das Almas, Chapada Diamantina-Bahia, Brazil. Royal Botanical Garden, Kew. Pp.152-154.

Gentry, A.H. \& Grose, S.O. 2007. Bignoniaceae. In: Funk, V.; Hollowell, T.; Berry, P.; Kelloff, C. \& Alexander, S.N. (eds.). Checklist of the plants of the Guiana Shield (Venezuela: Amazonas, Bolivar, Delta Amacuro; Guyana, Surinam, French Guiana). Contributions from the United States Nacional Herbarium 55: 214-220.

Gomes, A.P.S.; Rodal, M.J.N. \& Melo, A.L. 2006. Florística e fitossociologia da vegetação arbustiva subcaducifólia no Município de Buíque, Pernambuco. Acta Botanica Brasilica 20: 37-48.

Gomes-Jr., J.C. 1957. Flora do Itatiaia I - Bignoniaceae. Rodriguésia 32: 111-127.

Grose, S.O. \& Olmstead, R.G. 2007a. Evolution of a charismatic neotropical clade: Molecular phylogeny of Tabebuia s. 1., Crescentieae, and allied genera (Bignoniaceae). Systematic Botany 32: 650-659.

Grose, S.O. \& Olmstead, R.G. 2007b. Taxonomic revisions in the polyphyletic genus Tabebuia s.1. (Bignoniaceae). Systematic Botany 32: 660-670.

Harris, J.G. \& Harris, M.W. 2001. Plant identification terminology: an illustrated glossary. $2^{\text {nd }}$ ed. Spring Lake Publishing, Spring Lake. 206p.

Hickey, L.J. 1973. Classification of the architecture of dicotyledonous leaves. American Journal of Botany 60: 17-33.

Judd, W.S.; Campbell, C.S.; Kellogg, E.A.; Stevens, P.F. \& Donoghue, M.J. 2002. Plant systematics: a phylogenetic approach. Sinauer, Sunderland. 576p.

Laroche, R.C.M. 1973. O gênero Adenocalymna Mart. ex Meisn. (Bignoniaceae) dos estados da Guanabara e Rio de Janeiro. Loefgrenia 56: 1-10. 
Li, J. 2008. Phylogeny of Catalpa (Bignoniaceae) inferred from sequences of chloroplast $n d h-\mathrm{F}$ and nuclear ribosomal DNA. Journal of Systematics and Evolution 46: 341-348.

Lohmann, L.G. 2006. Untangling the phylogeny of neotropical lianas (Bignonieae, Bignoniaceae). American Journal of Botany 93: 304-318.

Lohmann, L.G. 2013. Bignoniaceae. In: Forzza, R.C. et al. (eds.). Lista de espécies da flora do Brasil. Jardim Botânico do Rio de Janeiro. Disponível em $<$ http://floradobrasil.jbrj.gov.br/jabot/floradobrasil/ FB112305>. Acesso 19 Mar 2013.

Lohmann, L.G. \& Hopkins, M.J.G. 1999. Bignoniaceae. In: Ribeiro, J.E.S.; Hopkins, M.J.G.; Vicentini, A.; Sothers, C.A.; Costa, M.A.S.; Brito, J.M.; Souza, M.A.D.; Lohmann, L.G.; Martins, L.H.P.; Assunção, P.A.C.L.; Pereira, E.C.; Silva, C.F.; Mesquita, M.R. \& Procópio, L.C. (eds.). Flora da Reserva Ducke: guia de identificação das plantas vasculares de uma floresta de terra-firme na Amazônia Central. Instituto Nacional de Pesquisas da Amazônia, Manaus. Pp. 96-100.

Lohmann, L.G. \& Pirani, J.R. 1996. Tecomeae (Bignoniaceae) da Cadeia do Espinhaço, Minas Gerais e Bahia, Brasil. Acta Botanica Brasilica 10: 103-138.

Lohmann, L.G. \& Pirani, J.R. 1998. Flora da Serra do Cipó: Bignoniaceae. Boletim de Botânica da Universidade de São Paulo 17: 127-153.

Lohmann, L.G. \& Pirani, J.R. 2003. Flora de GrãoMogol, Minas Gerais: Bignoniaceae. Boletim de Botânica da Universidade de São Paulo 21: 109-121.

Lohmann, L.G. \& Silva-Castro, M.M. 2009. Bignoniaceae. In: Plantas raras do Brasil. Guilietti, A.M.; Rapini, A.; Andrade, M.J.G.; Queiroz, L.P. \& Silva, J.M.C. (orgs.). Conservação Internacional, Belo Horizonte. Pp. 96-100.

Lohmann, L.G. \& Ulloa, U. 2011. Bignoniaceae in iPlants prototype Checklist. Disponível em $<$ http:// www.iplants.org>. Acesso em 1 Nov 2011.

Manning, S.D. 2000. The genera of Bignoniaceae in the southeastern United States. Harvard Papers in Botany 5:1-77.

Macbride, J.F. 1961. Flora do Peru. Bignoniaceae. Publications of the Field Museum of Natural History, Botanical Series 13: 3-101.

Melo; J.I.M. 2012. Flora do Parque Nacional do Catimbau, Pernambuco, Brasil: Boraginaceae sensu lato. Biotemas 25: 109-120

Miers, J. 1863. Report on the plants collected by Mr.Weir, especially the Bignoniaceae. Proceedings of the Royal Horticultural Society London 3: 179-202.

MMA - Ministério do Meio Ambiente. 2002. Avaliação e ações prioritárias para a conservação da biodiversidade da Caatinga. Universidade Federal de Pernambuco, Conservation International, Fundação Biodiversitas, Brasília.

Nakajima, J. 2013. Acritopappus. In: Forzza, R.C. et al. (eds.). Lista de espécies da flora do Brasil. Jardim Botânico do Rio de Janeiro. Disponível em $<$ http://floradobrasil.jbrj.gov.br/jabot/floradobrasil/ FB111654>. Acesso em 15 Mar 2013.

Oliveira, A.K.M.; Scheleder, E.J.D. \& Favero, S. 2008. Caracterização morfológica, viabilidade e vigor de sementes de Tababuia chrysotricha (Mart. ex. Benth) Standl. Revista Árvore 32: 1011-1018.

Olmstead, R.G.; Zjhra, M.L.; Lohmann, L.G.; Grose, S.O. \& Eckert, A.J. 2009. A molecular phylogeny and classification of Bignoniaceae. American Journal of Botany 96: 1731-1743.

Parker, T. \& Bailey, B. 1991. A biological assessment of the Alto Madidi region and adjacent areas of Northwest Bolivia. Conservation International 1: $1-108$.

Pool, A. 2008. A review of the genus Pyrostegia (Bignoniaceae). Annals of Missouri Botanical Garden 95: 495-510.

Queiroz, L.P. 2009. Leguminosas da Caatinga. Universidade Estadual de Feira de Santana, Feira de Santana. 467p

Radford, A.E.; Dickison, W.C.; Massey, J.R. \& Bell, C.R. 1974. Vascular plants systematics. Harper \& Row, New York. 891p.

Rizzini, C.M.; Agarez, F.V.; Andrade, L.H.C. \& Azevedo, A.P. 1997. A família Bignoniaceae na APA de Maricá, Rio de Janeiro, Brasil. Acta Botanica Brasilica 11: 153-163.

Rodal, M.J.N.; Andrade, K.V.A.; Sales, M.F. \& Gomes, A.P.S. 1998. Fitossociologia do componente lenhoso de um refúgio vegetacional no município de Buíque, Pernambuco. Revista Brasileira de Biologia 58: 517-526.

Sales, M.F; Mayo, S.J. \& Rodal, M.J.N. 1998. Plantas vasculares das Florestas Serranas de Pernambuco. Universidade Federal Rural de Pernambuco, Recife. $130 \mathrm{p}$.

Sandwith, N.Y. \& Hunt, D.R. 1974. Bignoniáceas. In: Reitz, R. Flora ilustrada catarinense. Herbário Barbosa Rodrigues, Itajaí. 172p.

Santos, L.L.; Alves, A.S.A. Alves \& Sales, M.F. 2009. Bignoniaceae. In: Alves, M.; Araújo, M.F.; Maciel, J.R. \& Martins, S (eds.). Flora de Mirandiba. Associação Plantas do Nordeste, Recife. Pp. 84-89.

Schneider, E.P.M. \& Londero, I.W.B. 1965. Flora Ilustrada do Rio Grande do Sul - Bignoniaceae. Boletim do Instituto de Ciências Naturais 25: 7-37.

Scudeller, V.V. 2004. Bignoniaceae Juss. no Parque Estadual Serra da Canastra, Minas Gerais, Brasil. Inheringia 59: 59-73.

Scudeller, V.V. \& Carvalho-Okano, R.M. 1998. Bignonieae (Bignoniaceae) no Parque Estadual 
do Rio Doce, Minas Gerais, Brasil. Inheringia 51: 79-133.

Silva-Castro, M.M. \& Queiroz, L.P. 2003. A família Bignoniaceae na região de Catolés, Chapada Diamantina, Bahia, Brasil. Sitientibus, Série Ciências Biológicas 3: 3-21.

Souza, V.C. \& Lorenzi, H. 2008. Botânica Sistemática: um guia ilustrado para identificação das famílias de Angiospermas da flora brasileira, baseado em APG II. $2^{\text {a }}$ ed. Instituto Plantarum, Nova Odessa. 57p.

Stafleu, F.A \& Cowan, R.S. 1989. Taxonomic literature: a selective guide to botanical publications and collections with dates, commentaries and types. Vol. 3. $2^{\text {nd }}$ ed. Bohn, Scheltema \& Holkema, Utrech. $980 \mathrm{p}$.

Standley; P.C.; Williams, L.O. \& Gibson, D.N. 1974. Flora of Guatemala. Fieldiana: Botany 24: 153-232.

Vellozo, J.M.C. 1825 [1829]. Florae fluminensis. 6: 246. Rio de Janeiro.

Zjhra, M.L.; Sytsma, K.J. \& Olmstead, R.G. 2004. Delimitation of Malagasy tribe Coleeae and implications for fruit evolution in Bignoniaceae inferred from a chloroplast DNA phylogeny. Plant Systematics and Evolution 245: 55-67. 